\title{
PELATIHAN PENULISAN CERITA DETEKTIF BERTEMA MASALAH DOMESTIK BAGI ANGGOTA KOMUNITAS PENULIS PEREMPUAN INDONESIA DI BANDUNG
}

\author{
Lestari Manggong, Kamelia Gantrisia dan Ida Farida \\ Program Studi Sastra Inggris Universitas Padjadjaran \\ E-mail: lestari.manggong@unpad.ac.id
}

\begin{abstract}
ABSTRAK. Cerita detektif, sebagai genre karya fiksi, khususnya yang ditulis oleh penulis perempuan masih sangat minim keberadaannya di Indonesia. Berangkat dari fakta ini, maka tercetuslah kegiatan PPM ini. PPM ini merupakan bagian dari kegiatan penelitian tentang deduksi Sherlock Holmes, yang melibatkan anggota Komunitas Penulis Perempuan (KPPI) Bandung. Melalui PPM ini, anggota KPPI Bandung dibekali pengetahuan mengenai penulisan cerita detektif dengan cara pengadaan pelatihan penulisan cerita detektif bertema masalah domestik. Tema masalah domestik ini dipilih karena tema inilah yang erat dengan keseharian penulis perempuan di KPPI Bandung yang semuanya adalah ibu-ibu. PPM ini bertujuan untuk memperkaya khasanah bacaan cerita detektif karya penulis perempuan di Indonesia. Untuk itu, maka PPM ini diproyeksikan dapat membantu penulis perempuan untuk dapat lebih mengasah kreatifitasnya menulis cerita detektif. Metode yang digunakan dalam pembahasan tentang kegiatan PPM ini adalah metode kualitatif, melalui observasi kegiatan sepanjang pelatihan. Hasil yang diperoleh dari pelatihan ini adalah pemetaan topik-topik yang berpotensi menjadi titik tolak rancangan cerita detektif yang akan ditulis. Kesimpulan yang diperoleh adalah tahap brainstorming dan clustering membantu peserta pelatihan dalam hal pemetaan topik.
\end{abstract}

Kata kunci: cerita detektif; penulis wanita; desain cerita detektif; media sosial.

ABSTRACT. Detective stories, as a genre of fiction, especially those written by female writers are still very few in number in Indonesia. It is based on this fact that this activity of Community Engagement (Pengabdian pada Masyarakat/PPM) was initiated. This PPM is part of a research activity on Sherlock Holmes deduction, which involves members of the Women's Writers Community (Komunitas Penulis Perempuan Indonesia/KPPI) Bandung. Through this PPM, members of the KPPI Bandung are provided with knowledge about writing a detective story by conducting a workshop on detective story writing on theme relating to domestic issues. This theme on domestic issues was chosen because it is closely related to the daily lives of the female writers of KPPI Bandung, most of whom are mothers or married women. This PPM aims to enrich the number of detective stories by female writers in Indonesia. For this reason, the PPM is projected to help female writers to further hone their creativity in writing detective stories. The method used is qualitative method, through observation of activities throughout the workshop. The results obtained from this training are mapping topics which are potential to be the starting point for the design of detective stories to be written. The conclusion is that brainstorming and clustering helped the participants in mapping out the topics for the stories.

Key words: detective story; female writers; detective story design; social media.

\section{PENDAHULUAN}

Tulisan ini merupakan pengkajian atas kegiatan PPM yang tercetus dari kurangnya genre cerita detektif yang ditulis oleh penulis perempuan di Indonesia. Berangkat dari penelitian tentang deduksi Sherlock Holmes, PPM ini merupakan kegiatan yang berdampingan dengan penelitian tersebut. Sebagai upaya untuk memperkaya khasanah bacaan di Indonesia, maka PPM ini diproyeksikan dapat membantu penulis perempuan untuk dapat lebih mengasah kreatifitasnya menulis cerita detektif. Cerita detektif yang diproyeksikan dapat dihasilkan dan diterbitkan adalah cerita detektif yang bertema masalah domestik. Tema ini dipilih karena tema inilah yang paling dekat dengan keseharian para penulis perempuan yang tergabung dalam Komunitas Penulis Perempuan Indonesia (KPPI) Bandung, yang sebagian besar adalah ibu-ibu yang telah berkeluarga.

PPM ini merupakan bagian dari kegiatan penelitian tentang deduksi Sherlock Holmes, yang melibatkan anggota Komunitas Penulis Perempuan (KPPI) Bandung. Kegiatan PPM ini terkait dengan riset HIU dalam hal kesamaan genre karya fiksi detektif yang digunakan sebagai acuan penulisan cerita detektif. Dalam pelaksanaannya, PPM ini juga terintegrasi dengan KKN mahasiswa. Oleh sebab itu, selain 2 anggota tim (dosen), dalam PPM ini terdapat pula 6 mahasiswa KKN semester 5. Melalui PPM ini, anggota KPPI Bandung dibekali pengetahuan mengenai penulisan cerita detektif dengan cara pengadaan pelatihan penulisan cerita detektif bertema masalah domestik. Tema masalah domestik ini dipilih karena tema inilah yang erat dengan keseharian penulis perempuan di KPPI Bandung yang semuanya adalah ibu-ibu. PPM ini bertujuan untuk memperkaya khasanah bacaan cerita detektif karya penulis perempuan di Indonesia. Untuk itu, maka PPM ini diproyeksikan dapat membantu penulis perempuan untuk dapat lebih mengasah kreatifitasnya menulis cerita detektif.

\section{METODE}

Metode penelitian yang digunakan adalah kualitatif, yang diaplikasikan untuk menilai hasil observasi atas yang dilakukan oleh peserta pelatihan. Bahan yang ditelaah 
dalam artikel ini diambil dari hasil kegiatan pelatihan penulisan cerita detektif bertema masalah domestik yang diikuti oleh anggota KPPI Bandung. Jenis metode observasi diaplikasikan dalam penelitian ini sebagai "the method of viewing and recording the actions and behaviors of participants" (Mertens: 16-19). Pengumpulan bahan dilakukan dengan mengobservasi kegiatan brainstorming dan clustering topik yang dilakukan oleh peserta pelatihan, untuk menentukan topik-topik apa saja yang berpotensi untuk dipilih menjadi titik tolak cerita yang akan ditulis.

Dalam proses observasi, partisipan ditempatkan dalam setting yang natural, yang sangat bergantung pada "information gathered by actually talking directly to people and seeing them behave and act within their context" (Creswell, 2014:268). Reaksi partisipan diobservasi, begitu juga respons, pertanyaan, dan komentar yang dilontarkan terkait kata atau frase yang berhasil dikumpulkan dalam proses brainstorming. Observasi ini kemudian mengantar pada penelaahan tentang pengaruh media sosial dalam tendensi penentuan kasus dalam rancangan cerita detektif yang ditulis oleh penulis perempuan.

\section{HASIL DAN PEMBAHASAN}

Pelatihan diawali dengan pengenalan anggota tim PPM, yang dilanjutkan dengan pengenalan kegiatan pelatihan yang dilakukan. Kemudian, Ketua Tim PPM memberi pengantar tentang formula cerita detektif, yang kemudian dilanjutkan dengan pengantar tentang cerita detektif lain sebagai rujukan (Detektif Conan dan Agatha Christie) seperti dijabarkan sebagai berikut:

\section{Pengantar tentang Formula Cerita Detektif}

Sebagai cerita detektif yang paling kanon, kisahkisah Sherlock Holmes sering dijadikan acuan contoh cerita detektif. Sebuah cerita detektif sangat formulaik, yang berarti bahwa desain struktur ceritanya mengikuti konvensi yang tetap. Todorov (1977) dalam pengamatannya tentang tipologi fiksi detektif menggaris bawahi bahwa "[Whodunit] novel contains not one but two stories: the story of the crime and the story of the investigation" (Todorov: 44). Lebih khusus lagi, ia menjelaskan lebih lanjut bahwa "the first - the story of the crime-tells "what really happened," whereas the second - the story of the investigation - explains "how the reader (or the narrator) has come to know about it" (Todorov: 45). Yang diimplikasikan dari pengamatan Todorov adalah bahwa kedua cerita yang dihadirkan (cerita tentang kasus dan cerita tentang proses investigasi kasus tersebut) memiliki hubungan sebab-akibat; proses investigasi tidak akan ada jika tidak ada kasus. Sebagai gambaran yang lebih jelas, bagian berikut akan menyediakan contoh cerita detektif yang diambil dari cerita perdana Sherlock Holmes berjudul A Study in Scarlet.

Dalam A Study in Scarlet terdapat dua bagian cerita dan dua kasus pembunuhan. Bagian I mengantar tentang latar belakang Dr. Watson, seorang veteran perang yang kemudian menjadi narator cerita pemecahan kasus-kasus yang ditangani Holmes. Kemudian Holmes menerima telegram dari seseorang yang membutuhkan bantuannya memecahkan sebuah kasus pembunuhan. Setelah ini, pembaca diantar ke TKP untuk melihat Kasus Pembunuhan I. Korban pembunuhan bernama Enoch Drebber. Ketika Holmes mengobservasi TKP, ia menemukan dua petunjuk penting: Tulisan "RACHE" di dinding dan cincin perempuan. Proses investigasi pun kemudian berlangsung, dan cara yang ditempuh untuk menemukan pemilik cincin adalah dengan cara mengiklankannya di koran. Upaya ini membuahkan hasil, karena tidak lama setelah diiklankan, ada seorang wanita tua mengaku bahwa cincin tersebut adalah milik anaknya. Plot kemudian bergulir ke Kasus Pembunuhan II. Kali ini korbannya bernama Stangerson. Dari hasil observasi di TKP, ditemukan tiga petunjuk pening: Tulisan "RACHE" di dinding, pipa rokok, dan kotak berisi 2 buah pil. Dalam proses investigasi, kedua pil dites, dan salah satunya ternyata racun. Kasus pembunuhan kemudian berhasil dipecahkan Holmes setelah Holmes menangkap Jefferson Hope, seorang supir taksi yang berhasil dilacak oleh teman-teman jalanan Holmes.

Setelah itu, plot masuk ke Bagian II, yang menyediakan cerita tentang Jefferson Hope di Amerika. Bagian II ini diawali dengan narasi kesaksian Hope di depan Lestrade, Holmes, dan Watson. Hope akan menikah dengan Lucy (si pemilik cincin), namun ditentang oleh warga di sana karena mereka berasal dari dua keyakinan yang berbeda. Lucy diberi dua pilihan: menikahi Joseph Stangerson atau Enoch Drebber. Lucy menolak keduanya. Kemudian, diketahui bahwa Lucy menghilang. Hope curiga Lucy diculik oleh Stangerson atau Drebber. Ternyata kecurigaannya benar. Stangerson menculik Lucy, dan Lucy dinikahkan secara paksa dengan Drebber. Pernikahan paksa ini membuat Lucy depresi dan akhirnya meninggal. Karena inilah akhirnya Hope memutuskan untuk membalas dendam kepada Stangerson dan Drebber. Bagian II ini kemudian ditutup oleh Watson, yang menganjurkan agar pemecahan kasus ini ditulis menjadi sebuah cerita. Namun Holmes menolak anjuran Watson. Tetapi akhirnya Watson kemudian memutuskan untuk tetap menulis cerita-cerita Holmes.

Dalam contoh tersebut tampak bahwa "the story of the crime" yang dimaksud Todorov adalah Bagian I, yang menjabarkan dua kasus pembunuhan dan menyingkap pelakunya. "The story of the investigation" terdapat di Bagian II, ketika pembaca diberikan informasi tentang apa yang melatarbelakangi Hope membunuh Stangerson dan Drebber. Dalam plot cerita detektif, hal ini oleh Todorov disebut sebagai dualitas cerita dalam novel "whodunit" (who has done it). Cerita 1 menceritakan apa yang sesungguhnya terjadi, dan menurut pengamatan Todorov cerita ini tidak ada tapi nyata. Cerita 2 menjelaskan bagaimana narator mengetahui apa yang sesugguhnya terjadi, dan menurut pengamatan Todorov cerita ini ada tapi tidak 
signifikan. Secara lebih rinci, cerita detektif harus memiliki unsur-unsur sebagai berikut:

1. Harus terdapat 1 detektif, dan minimal 1 penjahat dan 1 korban.

2. Penjahatnya membunuh karena alasan pribadi.

3. Tidak ada percintaan dalam cerita detektif.

4. Penjahatnya memiliki pekerjaan ataupun posisi penting.

5. Segala sesuatunya harus dijelaskan secara rasional.

6. Tidak melibatkan analisis psikologis.

7. Mengikuti rumus: "author : reader = criminal ; detective"

8. Hindari menghadirkan situasi dan solusi yang mudah ditebak (S. S. Van Dine (1928) dalam Todorov, 1977).

Daftar tersebut merupakan "ramuan" yang dapat membantu menghasilkan cerita detektif yang bagus. Selain yang disebutkan di daftar tersebut, elemen-elemen penting lain yang juga perlu disertakan adalah:

1. Misteri: ada yang terselubung.

2. Thriller: plotnya seru, banyak kejutan.

3. Suspense: menggugah rasa penasaran.

Formula inilah yang diperkenalkan kepada partisipan pelatihan menulis cerita detektif, sebagai pengetahuan dasar untuk menulis cerita detektif. Sebelum tahap penulisan dapat dimulai, para partisipan diberi latihan brainstorming dan clustering ide. Hasil dari dua kegiatan ini adalah cikal bakal kasus yang dapat dianggap sebagai bahan mentah untuk merancang ceritanya.

\section{Penjabaran Contoh Cerita Detektif Lain sebagai Rujukan}

Rujukan yang digunakan dalam PPM ini adalah cerita detektif komik Jepang (manga) Detektif Conan dan karya Agatha Christie.
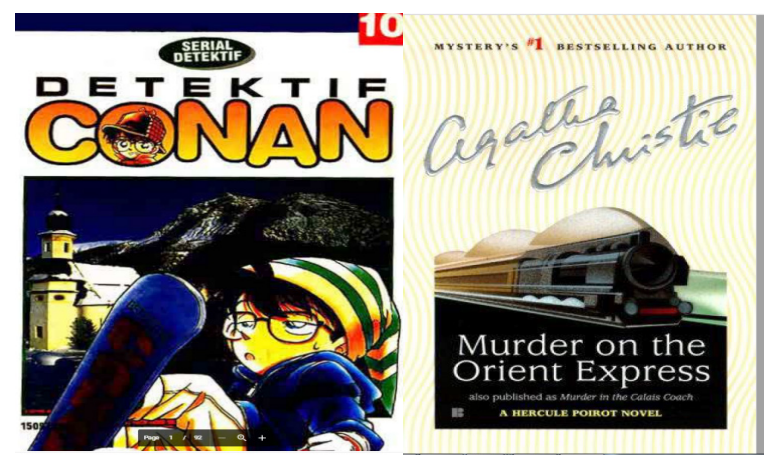

(Sumber: Internet)

Gambar 1. Detektif Conan dan Cerita detektif Agatha Christie

Sekilas tentang Conan:

- Nama aslinya adalah Shinichi Kudo, awalnya ia adalah seorang detektif SMA yang terkenal.

- Kecintaannya akan cerita detektif berasal dari Sang Ayah yang merupakan penulis kisah Misteri.

- Ia merupakan fans berat dari Sherlock Holmes.

- Nama Conan diambil dari nama Sir Arthur Conan Doyle (Penulis Sherlock Holmes) dan nama Rampo
Edogawa (penulis novel misteri di Jepang zaman dulu).

- Alasan tubuhnya mengecil layaknya anak SD disebabkan saat Shinichi tertangkap basah, ia tengah merekam dua orang mencurigakan yang tengah melakukan penjualan illegal. Ia kemudian diberi obat yang seharusnya merenggut nyawa Shinichi tapi karena obat itu belum sempurna, alih-alih mati, tubuh Shinichi justru mengecil seperti anak SD.

Tahap penyelesaian kasus ala Conan:

- Melihat hal-hal yang janggal dari TKP.

- Mencari bukti dengan sangat teliti dari hal terkecil sekalipun.

- Berpikir dari berbagai sudut pandang.

- Aktif bertanya pada siapapun yang menjadi saksi atau calon tersangka.

- Memiliki rasa penasaran yang tinggi.

- Menganalisis dari semua bukti yang telah dikumpulkan.

- Menunjuk tersangka.

\section{Contoh Kasus:}

Terjadi sebuah pencopetan di Kedai Sushi dengan hanya menyisakan satu petunjuk yaitu bekas darah di lengan baju pencopetnya yang sudah hilang. Lalu, Conan menggunakan analisisnya: bekas darah tidak mudah hilang jika hanya dibersihkan menggunakan air saja. Bekas darah dapat dihilangkan dengan bahan makanan yang mengandung protoase; enzim yang bisa memecah protein. Jadi, bekas darahnya akan hilang jika di serat bajunya diusap dengan bahan makanan tersebut. Makanan yang mengandung Protoase adalah jahe dan lobak. Tapi jika menggunakan jahe, bekas jahe tersebut akan terlihat. Jadi melalui analisisnya Conan dapat menyimpulkan bahwa sang tersangka adalah pelanggan yang memesan makanan yang terdapat lobak di dalamnya. Dan karena ia memiliki sifat peka akan sekitar, Conan secara otomatis mendengar siapa yang di awal memesan makanan yang mengandung lobak tersebut.

Ringkasan cerita Murder on the Orient Express: Pra kejadian

Hercule Poirot melakukan perjalan menuju Istanbul menggunakan kapal, kemudian pulang ke London untuk memutuskan libur dari pekerjaannya. Ia menaiki kereta Orient Express dan terjadi kasus pembunuhan selama perjalanan yang harus diselesaikannya.

\section{Malam kejadian}

Hercule Poirot melihat wanita berlari di lorong kereta pada malam pembunuhan. Korban bernama Racchet, dan ia bekerja sebagai penjual barang antik. Ia memiliki masalah dengan mafia Italia. Sebelum tewas, ia menerima surat ancaman.

Racchet Ditemukan dalam keadaan tewas dengan 12 tusukan tak berpola di badan. Di lokasi juga ditemukan 
jam korban yang pecah terakhir pukul 1.15 dan obat penenang bernama barbital. Korban dinyatakan tidak melawan saat dieksekusi, padahal korban memilki pistol untuk melindungi diri. Detektif menyatakan korban dalam keadaan gelisah karena efek kafein dan barbital sehingga tidak dapat melawan. Ditemukan saputangan wanita berinisial $\mathrm{H}$, pembersih pipa rokok, dan surat ancaman yang telah dibakar bertuliskan "darah Daisy di tanganmu, kau akan mati untuk itu”. Kemudian detektif langsung mengaitkan pada kasus penculikan dan pembunuhan seorang anak bernama Daisy dari keluarga militer yang memiliki seorang ayah bernama Kolonel Amstrong dan pelakunya adalah korban yang benama Cassetti.

Investigasi 1: Alibi para penumpang

1. Dr.Arbuthnot/Kolonel Arbuthnot

Dr. Arbuthnot adalah seorang dokter yang mengidentifikasi korban dan menentukan waktu kematian korban dengan melihat jejak jam yang pecah dan menentukan cara kematiannya dengan ditusuk secara brutal.

2. Hector McQueen

Hector McQueen bekerja sebagai pengelola keuangan korban selama satu tahun 20 hari dan mengatur perjalanan korban. Selain itu dia adalah seorang pengacara dan hanya menyukai uang korban. Ia melihat korban hinga pukul 10 malam untuk membahas penjualan di Italia dan ingin memeriksa pembukuannya. Ia bersama Dr.Arbuthnot hingga pukul 2 pagi. Ia memiliki surat ancaman korban bertuliskan "awas kau, tak ada yang boleh menipu kami”. Ia juga menuduh Biniamino Marquez karena rasnya latin.

3. Mrs. Hubbard

Mrs. Hubbard mengatakan bahwa ada seseorang di kamarnya yang dicuragi adalah pembunuhnya dengan barang bukti kancing dari salah satu seragam kondektur kereta. Tapi ketika ia diinvestigasi, Michel berada di situ dan ia tidak kehilangan kancingnya. Ia mencoba meyakinkan kondektur, tapi tidak berhasil. Ia menyatakan pembunuhnya adalah seorang pria, dan ia mengatakan bahwa ia mengetahui tentang kasus Daisy Amstrong,

4. Pierre Michel

Pierre Michel adalah kondektur kereta. Ia bersama Bouc dan detektif saat menginterogasi Mrs. Hubbard

5. Edward Henry Masterman

Edward Henry Masterman adalah pelayan korban, mengantarkan sarapan untuk korban di pagi hari. Ia terakhir melihat korban pada pukul 9 malam. Sambil membawakan kopi dan menggantung seragamnya, ia menyatakan korban sedang gelisah dan meminta kopi pada malam hari. Korban ingin terus terjaga karena isi surat ancaman yang diterimanya. Ia mengaku tidak mencapur kopinya dengan barbital, dan ia memilki penyakit yang dalam waktu dekat dapat mengakhiri hidupnya.

\section{Pilar Estrabados}

Pilar Estrabados adalah seorang perawat. Sebelum beralih profesi, ia adalah seorang misionaris, yang religious. Ia sekamar dengan Mary Debenham, pernah keluar sekali pada malam hari untuk mencari aspirin ke kamar Mrs. Hubbard. Ia sempat salah membuka pintu ke pintu kamar korban dan ditodong senjata sekitar pukul 10.40 malam. Ia mengaku tidak melihat Mary Debenham keluar dari kamarnya karena ia bukan tipe orang yang mudah terbangun dari tidur.

7. Gerhard Hardman

Gerhard Hardman adalah seorang professor di bidang mesin, orang Austria. Ia berada di kereta karena ia sedang melakukan perjalanan ke Jerman untuk menghadiri konferensi.

8. Biniamino Marquez

Biniamino Marquez pernah kabur dari penjara kemudian lari ke Amerika dan bersumpah tidak akan mencuri dan berbohong lagi. Ia sekamar dengan Edward Henry Masterman dan saling bersama hingga pagi. Ia memiliki bisnis mobil (3 showroom). Ia menyatakan dirinya bukan seorang sopir tapi dari foto yang terlihat saat investigasi, tampak bahwa ia adalah seorang sopir.

Jeda untuk hipotesis pertama

Bouc menuduh Mr. Masterman sebagai terduga tersangka dengan alasan bahwa orang yang mau mati tak takut kehilangan apapun. Tapi detektif Poirot meluruskan bahwa Marquez adalah teman sekamar Mr. Masterman dan mereka berdua di kamar sepanjang malam.

Setelah interogasi Hector McQueen, korban, Mrs. Hubbard, kondektur, Edward Henry Masterman, Pilar Estrabados, Gerhard Hardman, Biniamino Marquez.

9. Mary Debenham

Mary Debenham adalah orang pertama kali berkenalan dengan Hercule Poirot. Ia berasal dari Baghdad, bekerja sebagai guru geografi. Saat diinterogasi, dia menyatakan bertangan kidal, tak pernah ke Amerika, dan terlihat akrab dengan Dr.Arbuthnot/Kolonel Arbuthnot dan berbicara "jangan sekarang, setelah semua berakhir lalu tidak ada yang menyentuh kita". Ia kemudian bungkam atas pernyataan tersebut.

10. Putri Dragomiroff

Dalam penyeldikan, Putri Dragomiroff diinterogasi bersama Hildegarde Schmidt. Setelah makan malam ia tidur, jam 00.45 ia meminta Hildegarde Schmidt untuk memijit kakinya, kemudian tidur lagi. Ia mengetahui kasus penculikan Amstrong. Pengagum ibu Sonia Amstrong bernama Linda Arden, seorang aktris, yang merupakan ibu baptis dari Daisy .

11. Hildegarde Schmidt

Hildegarde Schmidt diinterogasi menggunakan bahasa Jerman agar tidak diketahui Putri Dragomiroff selaku majikannya. Saputangan berinisil H bukan miliknya dan terlalu mahal, ia diperintahkan majikannya untuk 
memanggil kondektur dan tidur lagi. Ia hanya melihat petugas kereta yang lain mengenakan seragam kondektur tapi bukan Michel dan petugasnya bertubuh kecil berjanggut pendek bersuara tinggi.

Kemudian ditemukan kimono merah di koper detektif dan ditemukan seragam kondektur yang kehilangan kancingnya di kamar Hildegarde Schmidt yang bukan miliknya. Kemudian ditemukan kunci untuk membuka kamar korban dan terdapat noda alkohol di seragam yang diduga milik Hector McQueen.

Detektif dan Bouc memeriksa berkas keuangan korban pada Hector McQueen. Setelah itu, terlihat Hector McQueen membakar berkas keuangan milik korban dan terbukti ada penggelapan uang yang dilakukan Hector McQueen terhadap korban.

\section{Investigasi 2}

1. Hector McQueen

Hector McQueen bersikeras bahwa ia tidak membunuh korban walaupun dengan bukti penggelapan uang yang dilakukannya terhadap korban. Ia membalikkan pernyataan detektif Porit, untuk apa ia membunuh sumber keuangannya. Kemudian Dr.Arbuthnot/ Kolonel Arbuthnot membela bahwa dia bersamanya hingga pagi pukul 2 sambil minum-minum.

2. Dr.Arbuthnot/Kolonel Arbuthnot

Dr.Arbuthnot/Kolonel Arbuthnot adalah satu satunya perokok di kereta. Ia kuliah kedokteran di tahun 1924, seorang penembak jitu, dan tidak mengenal Kolonel Amstrong. Pernyataannya tentang Mary Debenham bertentangan dengan temuan bahwa ia bertemu dengan Mary Debenham hanya satu kali. Padahal ia cukup akrab. Namun ia bersikeras bahwa Mary Debenham adalah wanita baik-baik.

Detektif Poirot curiga dengan Mary Debenham, kemudian kembali menginterogasi Hector McQueen

3. Hector McQueen (interogasi ketiganya)

Detektif Poirot mencurigai dia karena ia pengacara namun dari pendidikan non-formal. Padahal sebelumnya juga ada orang yang bernama McQueen yang terkenal di bidang yang sama. Pengacara tersebut ditugaskan sebagai jaksa penuntut pada kasus Kolonel Amstrong. Pengacara ini ditekan warga agar menjatuhkan hukuman pada seorang pembantu bernama Susane. Ternyata jaksa/pengacara itu adalah ayah dari Hector McQueen. Kemudian pembantu tersebut bunuh diri padahal ia tidak bersalah. Ketika bukti mengarah pada Cassetti, kejadian bunuh diri itu sudah lama terjadi dan mereka yang menekan ayah Hector McQueen untuk menjatuhkan hukuman kepada Susane yang berbalik menyerang sang ayah.

Kemudian detektif menemukan hipotesis baru bahwa Hector McQueen memiliki motif untuk menguras uang korban dan membalas dendam ayahnya. Kemudian hal tak terduga terjadi, Mrs. Hubbard ditusuk oleh seseorang yang diduga sebagai pelaku.

4. Countess Elena Andrenyi dan Count Rudolph Andrenyi

Seorang bangsawan, satu satunya orang yang memilki barbital, ternyata bernama Helena bukan Elena, saudari perempuan dari Sonia Amstrong dan secara mental telah hancur setelah kematian Daisy Amstrong

5. Gerhard Hardman

Menuduh Countess Elena Andrenyi sebagai pembunuhnya, kemudian detektif membongkar kebohongannya. Ternyata dia bukan orang Austria dan bukan professor. Nama aslinya Cyrus Bethman Hardman, bekerja menjaga Ratchett. Lokasi kamarnya sangat memungkinkan untuk melihat pelakunya dari celah kamarnya.

6. Mary Debenham

Dia berbohong tidak pernah ke Amerika. Sementara di saat kejadian penculikan Daisy Amstrong ia tinggal di rumah kolonel itu sebagai penjaga putri keluarga kolonel. Detektif menuduh Mary Debenham sebagai dalang dari pembunuhan kemudian meminta Countess Elena Andrenyi untuk menyaksikan dengan harapan Helena menjadi lebih baik, dia meracuni korban dengan barbital agar tidur hanya membuat pusing. Motifnya adalah dia mencintai Daisy Amstrong dan membalas dendam pada korban.

Kemudian datang Dr. Arbuthnot/ Kolonel Arbuthnot dan menembak detektif tapi hanya melukainya, kemudian Dr. Arbuthnot/ Kolonel Arbuthnot mengaku sebagai pembunuh korban dan bukan Mary Debenham. Kolonel Amstrong adalah komandanya yang memberikan kesempatan kuliah di kedokteran dan memberi masa depan padanya tapi Cassetting menghancurkan hidupnya. Setelah perlawanan, detektif menang dibantu oleh Bouc, kemudian ia meminta semua penumpang berkumpul di satu tempat untuk penentuan tersangka.

Saat dikumpulkan, detektif mengumpulkan fakta bahwa tidak ada satupun dari mereka yang merupakan pembunuh sejati. Kemudian Poirot juga menyimpulkan bahwa:

1. Pembunuhan ini untuk membebaskan jiwa Helena yang hancur.

2. Dr.Arbuthnot/Kolonel Arbuthnot adalah yang berdedikasi pada Kolonel Amstrong yang bertemu dengan Mary Debenham yang seperti ibu dari Daisy Amstrong dan Mary Debenham begitu dekat dengan adik perempuan Sonia Amstrong (Helena) yang menikahi bangsawan bernama Count Rudolph Andrenyi, Sonia Amstrong sendiri tewas setelah mendengar berita kematian putrinya saat melahirkan secara prematur.

3. Ibu baptis dari Daisy Amstrong yang memiiki saputangan berinisal $\mathrm{H}$ tapi dalam bahasa Rusia adalah $\mathrm{N}$ "Natalia Dragomiroff" dan ada juru masak keluarga amstrong yaitu Hildegarde Schmidt.

4. Pengasuh Daisy Amstrong yaitu Pilar Estrabados 
yang menjadi religius karena terlalu mabuk saat penculikan terjadi.

5. Ada pembantu Kolonel Amstrong saat perang dan menjadi pelayan kolonel setelah perang yaitu Edward Henry Masterman.

6. Sopir Kolonel Amstrong yaitu Biniamino Marquez mendapatkan jaminan dari sang majikan untuk pinjaman bank untuk membuat showroom mobil.

7. Ada polisi yang ditugaskan untuk kasus Amstrong tapi gagal dan berakhir pada bunuh dirinya Susane Michel selaku kekasih dari polisi itu dan yang menjadi jaksa pada saat itu adalah ayah Hector McQueen yang hidupnya hancur setelah kasus itu.

8. Kondektur Pierre Michel yang kehilangan adiknya, Susane Michel, akibat dari kasus ini.

9. Nenek Daisy Amstrong yaitu Mrs. Hubbard dengan nama panggung Linda Arden.

Kemudian detektif menyimpulkan bahwa semua penumpang ini adalah pelaku pembunuhan ini. Dan dalang dari kasus ini adalah Mrs. Hubbard, ia mengirim Hector McQueen untuk bekerja pada korban bersama Edward Henry Masterman agar dapat mengatur perjalanannya saat Pierre Michel bertugas.

\section{Pembekalan tentang Hoaks pada Minuman Suplemen Torpedo}

Kegiatan selanjutnya adalah pembekalan tentang hoaks pada minuman suplemen bermerk Torpedo. Pembekalan ini dilakukan untuk memberikan gambaran bagi peserta pelatihan tentang tahapan-tahapan yang dapat dicontoh untuk menelusuri kebenaran sebuah berita.

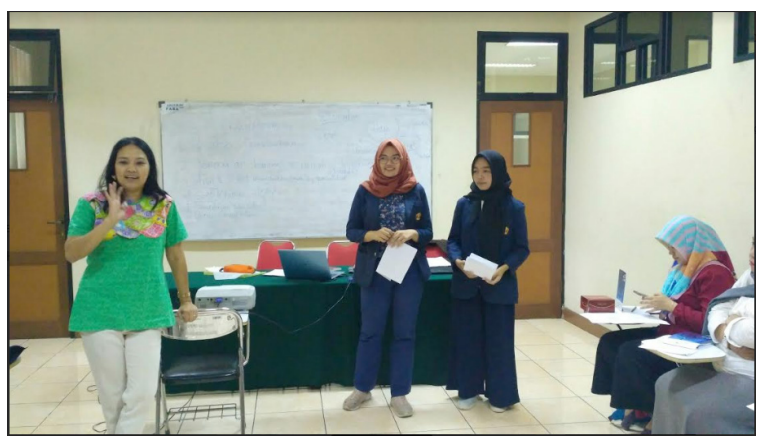

(Sumber: Koleksi Pribadi)

Gambar 1. Mahasiswa KKN memberi Pembekalan tentang Hoaks Minuman Torpedo.

Pembekalan tentang hoaks pada minuman suplemen bermerk Torpedo sengaja dipilih karena isu ini sangat dekat dengan keseharian ibu-ibu, yang memiliki anak yang sekolah dan khawatir anakanaknya akan terkena dampak dari minuman tersebut. Pembekalan yang dilakukan oleh mahasiswa Prodi Teknologi Pangan dan Prodi Farmasi ini secara detail memaparkan tahapan-tahapan yang perlu dicermati ketika menerima informasi tentang minuman yang membahayakan anak-anak. Pengetahuan tentang ilmu farmasi dan teknologi pangan yang diterapkan dalam analisis kandungan dalam minuman Torpedo membantu peserta mendapat gambaran yang lebih jelas tentang kandungan kimiawi apa saja yang berpotensi membahayakan tubuh.

\section{Brainstorming dan Clustering Topik Cerita/Kasus}

Tahap berikutnya adalah kegiatan brainstorming dan clustering topik untuk cerita atau kasus yang dapat digunakan sebagai titik tolak cerita. Kegiatan brainstorming dilakukan dengan cara secara spontan mendaftar kata-kata atau frasa apa saja yang merupakan topik domestik.

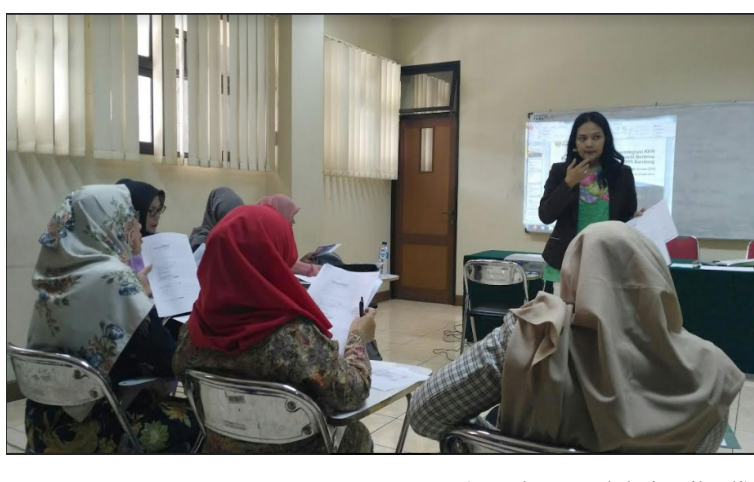

\section{Gambar 2. Brainstorming dan Clustering.}

Karena semua partisipan adalah ibu-ibu, maka topik yang muncul dalam brainstorming erat dengan urusan domestik atau urusan rumah tangga. Secara rinci, hasil brainstorming rancangan cerita detektif yang dikumpulkan adalah sebagai berikut:

1. Pelakor (perselingkuhan).

2. Pencurian barang-barang di rumah (misalnya tupperware).

3. Anak-anak:

- Ibu-ibu mengawasi anak-anak.

- Penculikan anak.

4. Gosip, rumor, atau hoaks.

5.Penyebaran penyakit.

6.Uang (misalnya uang belanja).

Setelah brainstorming, peserta pelatihan diarahkan untuk melakukan clustering (pengelompokan) kata-kata atau frasa yang telah didaftar tadi. Hasil clustering dapat diilustrasikan sebagai berikut:

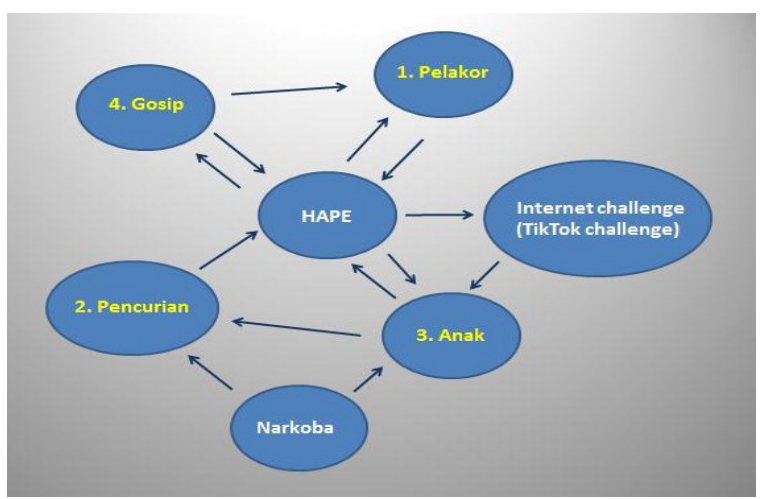

Gambar 3. Hasil Clustering 
Hasil clustering menunjukkan bahwa ada 3 topik yang berpotensi diangkat dalam cerita yang akan ditulis oleh peserta pelatihan, yaitu:

1. Pelakor,

2. Pencurian,

3. Anak, dan

4. Gosip.

Keempat topik ini dapat dijadikan titik tolak bagi peserta pelatihan untuk menentukan jenis kasusnya. Jika kasus sudah dapat ditentukan, maka bahan cerita akan berlanjut dari situ. Sebagai penentuan titik tolak, kegiatan brainstorming dan clustering ini maka sangat membantu proses perancangan cerita detektif yang akan ditulis.

\section{SIMPULAN}

Dari kegiatan pelatihan tersebut, maka kesimpulan yang diperoleh adalah tahap brainstorming dan clustering membantu peserta pelatihan dalam hal pemetaan topik. Topik yang telah dipetakan ini dapat membantu mereka menentukan bagaimana kasusnya dibangun, siapa kira- kira korbannya, dan apa motivasi dari tindakan kriminal yang dilakukan terhadap korban tersebut. Dengan demikian, maka cerita detektif akan dapat tersusun.

\section{UCAPAN TERIMAKASIH}

Tim PPM menyampaikan terimakasih kepada Universitas Padjadjaran, karena atas Hibah Internal Unpad (HIU) skema Riset Fundamental Unpad (RFU), maka kegiatan PPM ini dapat terselenggara.

\section{DAFTAR PUSTAKA}

Creswell, John W. 2014. Research Design: Qualitative, Quantitative, and Mixed Methods Approaches. U.S.A.: SAGE Publication.

Mertens, Donna M. 2010. Research and Evaluation in Education and Psychology. California: SAGE Publications, Inc.

Todorov, Tzvetan. 1977. The Typology of Detective Fiction. The Poetics of Prose (Tzvetan Todorov and Richard Howard). Oxford: Blackwell. 